furnished to them by Mr. Seymour Haden. In addition to being a diary, it contains a good deal of useful information, likely to be of service to the practitioner, concisely arranged. "The Chemist and Druggist's Diary" for 1876 fully maintains its reputation; it is published at the office of the Chemist and Druggist Journal. Messrs. Partridge and Cooper have sent "The Folio Scribbling Diary" for 1876, price 1s; "The Diary and Call-book," price 2s.; and "The Octavo Scribbling Diary," price 2s.,-all interleaved with blottingpaper.

\section{POST-MORTEM EXAMINATION OF THE REMAINS OF HARRIET LANE.}

\section{A Clinical Lecture, delivered at Westminster Hospital,}

BY THOMAS BOND, F.R.C.S., B.S. LoND., ASSISTANT-SURGEON TO THE HOSPITAL AND LECTURER ON PORENSIC ME DICINR.

Gentlemen,-As yoũ probably are aware, I was employed by the Treasury to make the post-mortem examination upon the human remains found in the possession of Henry Wainwright. I was at once fully impressed with the grave nature of the task committed to me, and approached it with a mind absolutely free from any preconceived ideas as to the guilt or innocence of the prisoner. This condition of mind it was of course necessary to maintain during the whole of the inquiry, as it was my business to interpret facts only, quite regardless of the result to the prisoner.

On the 16th of September I met $\mathrm{Mr}$. Larkin, who had already made a preliminary examination, and had given certain evidence before the magistrate. He had removed the abdominal and pelvic viscera, and very properly had placed them in jars which had previously been cleansed with distilled water. He had very carefully taken off the skull-cap without injuring the dura mater or brain; he also discovered a cut in the throat, to which he attributed death. But I proceeded to the investigation methodically and carefully, without troubling my mind with any theory or preconceived opinion.

There were, of course, two main questions to determine :1st, the cause of death; 2nd, the identity of the remains.

I found the body in a sealed coffin, the lid of which was partially of glass. This was a very convenient method for exposing the body to the jury, and also to the relatives. I had the remains removed from the vault into the yard, and on opening the lid the horrible and peculiar smell at once indicated an adranced stage of decomposition. Availing myself of Mr. Larkin's valuable assistance, I proceeded to the examination. The remains were laid on a table in an open yard, with a good light, and carefully placed in position. They consisted of ten pieces. (1) The head and neck, which was separated from the trunk between the sixth and seventh cervical vertebræ; (2) the trunk, includ. ing thorax, abdomen, and pelvis; ( 3 and 4 ) the two thighs, divided from the pelvis through the neck of each femur, (5 and 6) the two legs with the feet attached, separated from the thighs at the knee-joints; (7 and 8) the two arms, which were cut off at the shoulder-joints; $(9$ and 10$)$ the two hands, one being separated at the wrist and the other about two inches above. There was also found adhering to the body a quantity of white greasy material mixed with earth, which I subsequently found by chemical examination to be chloride of lime. This, I have no doubt, in a great degree contributed to the preservation of the superflcial parts of the body, by the formation of a coating of adipocere, which is the result of a chemical combination of a fatty acid with a mineral base, generally supposed to be ammonia, when the tissues become changed into adipocere; but in this case the base was probably lime. Where this covering of adipocere was deficient tbe flesh had eroded in patches. At other parts it had dried, appearing white, silvery, and smooth, as if stretched over the subjacent tissue. It certainly gave me the idea at first of numerous scars, similar to those produced by slight sralds. This appearance played an important part at the trial, as Mr. Aubin, the surgeon for the defence, cut out one of the patches and called it a scar.

From the nature of the hair, the shape and contents of the pelvis, and the slender limbs, it was evident at once that I had before me the complete body of an adult female, and that it had been hacked apart by a rough and unskilled hand. The woman had evidently been dead many months, for the face, the front of the thorax, and part of the abdomen were quite decayed. No trace of features could be distinguished, although Mr. Larkin made the discovery that the ears were pierced for earrings. The limbs, however, and the lower part of the abdominal walls were covered with the dark-brown greasy substance which I have described as adipocere, and on scraping away which, the skin underneath was found well preserved, but in a dry and shrivelled condition. The thoracic, abdominal, and pelvic viscera, with the exception of the uterus, were so much decomposed that no examination was made of them, but the condition of the uterus was accurately noticed. It was very small, not above an inch long, and not a quarter of an inch in thickness. The colour was very dark brown, and to the touch it felt like soap. It was carefully put aside and soaked in water for subsequent examination. The division of the body was undoubtedly of recent date, as proved by the freshly cut bone and muscle, the former hanging about the cut parts in chips, and the latter flaccid and not retracted from the cuts. The cutting seemed to have been done by a blunt adze or chopper, and the appearances were consistent with its having been done with a hatchet shown me by the police. The scalp was partially separated from the skull, and more particularly so on the right side, and attached to it was a quantity of curly auburn hair, which was fixed at the back of the head to a pad by a number of hair-pins. On the left side of the head the hair was clotted with a dark substance resembling dried blood. The sutures of the skull were well marked and distinct, with the exception of the frontal, which was quite obliterated. On the right side of the skull, just above the articulation of the posterior inferior edge of the parietal bone with the squamous portion of the temporal, there was a depressed fracture, the size of a sixpence, and at the back part of the depressed bone there was complete penetration of the skull by a hole large enough to admit a small bean. The fracture must have been caused by a hard, blunt substance, striking in a direction obliquely backwards and inwards. The fracture was not of recent date, the broken surfaces being of dark colour, and similar in appearance to the exposed portion of the skull. The depression was not easily seen at first sight, as it was filled up with a dark substance similar to that found about the body - viz., chloride of lime and earth, which was probably here mixed with blood. The fracture was somewhat stellated, but it did not extend into the lateral sinus.

The scalp was detached over the fracture and around it for a distance approximately of two inches, exposing the bone. There was a penetrating wound of the scalp, and when drawn forward the hole corresponded to a point on a level with, but an inch posterior to, the fracture. The under surface of the scalp around the bole was dark-coloured, and its substance infiltrated with blood to a depth of onesixteenth of an inch. The under surface of the uninjured portion of the scalp was of a pale-brown colour. The dura mater was detached from the skull-cap and entire, except opposite the fracture, where it was perforated. Its surface was of a light-grey colour, but exactly opposite the fracture it was very dark brown, and appeared thicker. On cutting through the membrane at the point of puncture, the dark colour was found to extend through to the under surface, and the brain in contact with it was dark-brown for a distance of half an inch around the hole. This was caused, I bad no doubt, by infiltrated blood, and I therefore formed the opinion that the injury was inflicted during life. On passing my finger through the hole in the dura mater into the substance of the brain, I found two spiculæ of bone. I enlarged the opening in the dura mater, and carefully removed the decomposed brain, which was in a semifluid condition, and of a light-brown colour; then carrying the exploration on in the direction of the hole through the skull, I found a mucb flattened bullet lying in the left hemisphere of the cerebellum. It must have entered the skull obliquely, 
from before backward, and had struck the occipital bone just behind and on the left side of the foramen magnum, causing a s'ight stellate fracture of the inner table. This bullet undoubtedly caused the injuries I have described. On removing the dura mater and the soft pulpy brain I discovered a second bullet lying on the posterior clincid processes of the sphenoid bone, which were both broken off. This bullet was slightly flattened on tha top only, and appeared to have entered the skull by direct impact. On further examination, I found a hole in the skull exactly above the base of the zygomatic process of the right tem. poral bone, and, passing my finger directly inwards along the base of the skull, and in a line with the petrous portion of the temporal bone, I found a large spicula of bone half-way between the hole and the position of the bullet. I found no appearance of effused blood in the track of this bullet inside the skull, but found a quantity of died blood around the external opening just in front of the ear. I formed the opinion that this wound was probably inflicted directly after deatb, as I should have expected to find evidences of blood in the track of the bullet had it been fired during life. The injury was of old date, and probably inflicted when life was ebbing, or directly after death.

A cut two inches long extended from the right side of the thyroid cartilage upwards to the left angle of the lower jaw, dividing all the tissues down to the vertebræ. The larynx was partly divided, and the cut, shallow and superficial at first, enlarged towards the left, and went deeply upwards under the angle of the jaw. It nearly divided the body of the third cervical vertebra, and extended through the transverse process on the left side. The surface of the wound was retracted and dried, quite the reverse of the flaceid and soft appearance of the cuts separating the limbs and trunk. It appeared to have been inflicted from the fron ${ }^{+}$, upwards and backwards; it was a clean cut, and must bave been done with a sharp instrument. The incision in the vertebra was dark and dry at the edge, but the deeper portinn was clean and very fresh-looking. I saw no appearance of blood in the wound, but there was a quantity of clotted blood around the left ear, and the hair on that side was matted together with blood. I could form no opinion as to w bether the cut was inflicted during life or after deatb, but it certainly did not appear a recent cut. About the cut in the vertebra I was much puzzled. The fresh-looking and moist surface of the deeper part of the cut seemed to indicate recent infliction. I decided to give no positive opinion with regard to the wound in the throat. I believed it to be of old date, but $I$ could not swear that it was not done in cutting up the body, especially as the tissue of the face and neck was much drier than the other portions of the body, and the parts had necessarily been somewhat more exposed during the careful examination of Mr. Larkin in the preliminary examination.

There were four teeth absent from the mouth-one upper incisor, one canine, and two lower incisors. They had evidently fallen out during decomposition. 'The canine and one of the lower incisors were afterwards found and replaced. The first bicuspid of the upper jaw was decayed to the root; all the other teeth were sound. The wisdom. tooth of the left upper jaw was still uncut, and the mucous membrane had to be removed to expose it. The upper incisor was slightly prominent. The cartilages of the ribs were not at all ossified. The bones of the skeleton were light and small, the cancellous tissue abundant, and the articular surfaces were cartilaginous and soft. The epiphyses bad united at the parts I examined-viz., the neck of the femur, the head of the humerus, and the articular surfaces of the tibia. From the above appearances $I$ inferred that the age of the decedsed was from twenty to twenty-five years.

The above is the substance of my report to the Treasury after my first examination. The subsequent examinations were made in the interest of the prisoner and in the presence of Mr. Aubin, a surgeon aupointed to watch the case for the defence. My acknowledgments are due to Mr. Aubin for the courteous behaviour and proper spirit with which he approached the investigation. During the course of it three more important observations were made. First, the discovery of the scar, which I was induced to look for through having heard Mr. Lane say before the magistrate that his daughter had a scar on one of her legs, but he did not know which. I first scraped the adipocere from the left leg, and failed to find one, but on carrying out the same process on the right leg, found most unmistakably a raised fibrous scar situated exactly over the fibula, about two inches below the head. It was about the size of a shilling, rather elongated from above downwards and backwards. The skin in front was bealthy, but much puckered and drawn, and at the back there was the usual white discolouration found after a burn or scald. The fibrous portion was brown and raised, almost keloid in its character, being at least an eighth of an inch thick.

We next turned our attention to the hands and feet, which were exceedingly slender and much dried; the nails were long, and there was no mark of a furrow on the ring finger. The feet measured eight and a half inches, and on comparing them with a boot of Harriet Lane's it was evident it would fit. Finally, we adjusted the parts as accurately as possible, which was not easy, owing to one or two vertebræ in the neck having got loose, and from the chopping up of the neck of the femur, which rendered it very difficult to fix the thighs in the exact anatomical position; however, we did our best, and after several trials found the exact measure. ment of the height was $4 \mathrm{ft} .11 \frac{1}{3}$ in.

I took possession of the third cervical vertebra and of the scar. I also cut off some of the hair, which I afterwards compared microscopically with some hair taken out of the grave at Whitechapel by Inspector For, and likewise with some hairs found on a hatchet and spade. Mr. Larkin took charge of the uterus, and of the pad and hair-pins found at the back of the head, in which he found subsequently a bullet flattened against the hair-pins.

(To be concluded.)

\section{THE WATER-SUPPLY OF THE METROPOLIS.}

NeARLY a hundred pages of the last Report of the Rivers' Pollution Commission are devoted exclusively to the past and present history of the water-supply of the metropolis. The quality of the London water has been the subject of many investigations, and as long ago as 1828 a Royal Commission was appointed to inquire and report upon the subject, and a more complete system of filtration was recommended. It was found, however, as had been predicted, that mere filtering could not, and does not, remove organic matters in solution, and that when the Thames, during heavy rains, received the flushings of the sewers, streets, and cesspools, the drinking-water supplied was often execrably bad in quality. No changes as to the intake were, however, made until 1848, when the Lambeth Company obtained an Act authorising them to remove their intake from Lambeth to Thames Ditton, above Teddington-lock, and consequently beyond the reach of the London sewage. In that and the following year the metropolis was severely visited by epidemic cholera, and in 1850 the General Board of Health (consisting of Lords Carlisle and Ashley, Mr. Chadwick, and Dr. Southwood Smith) reported decisively that in consequence of its hardness and its various modes of pollution, the Thames water ought to be abandoned for domestic purposes. In the following year another Commission was appointed to examine into the proposed new sources of supply, and the unfitness of the water procured both from the Thames and the Lea having been further demonstrated, an Act was passed in 1852, providing, among other things, that no water shall be taken by any company supplying the metropolis below Teddington, or from any tributary of the river within the range of the tide; that all storage reservoirs within five miles from St. Paul's shall be covered, and all water supplied for domestic purposes filtered. The immediate results of this Act were to remove the intakes of all the companies abore Teddington-lock. The East London Company also moved its intake beyond the reach of the tide in the Lea, and the Kent Company, having abandoned the polluted Ravensbourne, obtained its supply henceforth from deep wells sunk into 